\title{
EXCHANGE RATE RISK ON THE MORTGAGE MARKET
}

\author{
Ewa Siemińska, prof. \\ Nicolaus Copernicus University in Torun \\ Faculty of Economic Sciences and Management \\ E-mail:ewahsiem@econ.umk.pl
}

\section{Małgorzata Krajewska, PhD.}

Nicolaus Copernicus University in Toruń

Faculty of Economic Sciences and Management

E-mail:gosiak@econ.umk.pl

\begin{abstract}
Strict connections of the real estate market with the financial market are an unquestionable phenomenon at every level of investing, starting from the lowest individual investor, and finishing with national and transnational players. One of the more interesting examples of such a dependency is the problem of the risk of financing the real estate market, which results from numerous macro-, mezo- and microeconomic conditions, including, inter alias, the phenomenon of capital migration, supranational bank regulations or the development of currency exchange rates on world markets. The most recent example of such a dependency is, among others, the decision of the National Bank of Switzerland from the beginning of 2015 to abandon the Swiss franc-euro cap, which will go down in the history of the world financial market. Its global effects will surely be very difficult to assess, while the resulting turbulences and consequences for many (institutional, corporation and individual) market participants cause, on the one hand, awaiting a reaction and actions aimed at helping entities affected by the consequences of the mentioned decision and, on the other, many questions and doubts.

The paper will present current selected aspects concerning currency risk in the context of financing the residential real estate market and the directions of actions prepared in reaction to the abovementioned risk. Polish conditions will be presented against the background of examples of foreign solutions.

The aim of the work is to present:

1) the essence of currency risk in the context of the current financial situation of the Polish banking sector,

2) the most important directions of proposals for remedial actions aimed at mitigating the effects of the significant increase in the exchange rate of the Swiss franc in relation to the Polish currency,

3) a short overview of selected solutions/regulations regarding the exchange rate risk of mortgages taken out in a foreign currency in other countries.

The method employed was the critical analysis of the most-recent reports and recommendations of the National Bank of Poland, Polish Financial Supervision Authority, Polish Banking Union, and other experts on the subject of financing the real estate market, as well as a comparative analysis of solutions regarding currency risk in selected countries.
\end{abstract}

Key words: currency risk, real estate market financing, mortgages.

JEL Classification: R30, G10, G21

Citation: Foryś I., Putek-Szeląg E., 2015, Exchange Rate Risk on the Mortgage Market, Real Estate Management and Valuation, Vol. 23, No. 4, pp. 74-84.

DOI: $10.1515 /$ remav-2015-0038 


\section{Introduction}

The determinants of the global architecture of the financial system affect the situation in every region of the world through various transmission channels, reaching the level of national, local or individual budgets. In the second half of the XXI century, not so optimistic perspectives and scenarios regarding the growth of the most important world market economies, the situation on financial markets including the eurozone with the mounting problems of some countries, especially those such as: Greece, Cyprus, Spain or Italy, the instability of currency exchange rates, a lack of trust in many links of the financial system (at the international level, as well as at the level of individual countries), and also the escalating political crises comprise the environment of current national economies, affecting not only macro- but also microeconomic determinants. When we additionally bring to mind the procyclical nature of the functioning of the bank sector, and the tendencies to restrict financial reserves in periods when the market situation is promising and increase them in a period of economic crisis, we can observe great dynamics of the financial environment (CASE, SHILLER 2004; European Housing Review 2011; BOLEAT, COLES 2012; KAU et al. 2011; GROSSE 2012; KALlAKMAA-KaPSTA, KOLBRE 2013; OATLEY et al. 2013; PETRU 2014; SIEMIŃSKA 2013; ŚMIETANA 2014). That is why all kinds of decisions and regulations of a supranational level that regard Polish as well as foreign banks with branches in Poland engaged, among others, in financing the real estate market are also not insignificant. The specification of such financing is usually the strict connection of financial instruments with real estate, often serving to secure the receivables of banks. The special nature of mortgages results especially from:

1) mortgage security, which over the course of the loan contract has a tendency to change value when compared to other types of security,

2) long - when compared to other loans - period of loan agreements binding both sides of the contract,

3) relatively frequent securing of the loan with the mortgaged real estate.

Without a doubt, among the various current business determinants regarding the financial market, one of the most important is the earlier-mentioned decision of the National Bank of Switzerland to abandon the Swiss franc peg to the euro, which came as unexpected to many communities (Fig. 1; JORDAN 2015).

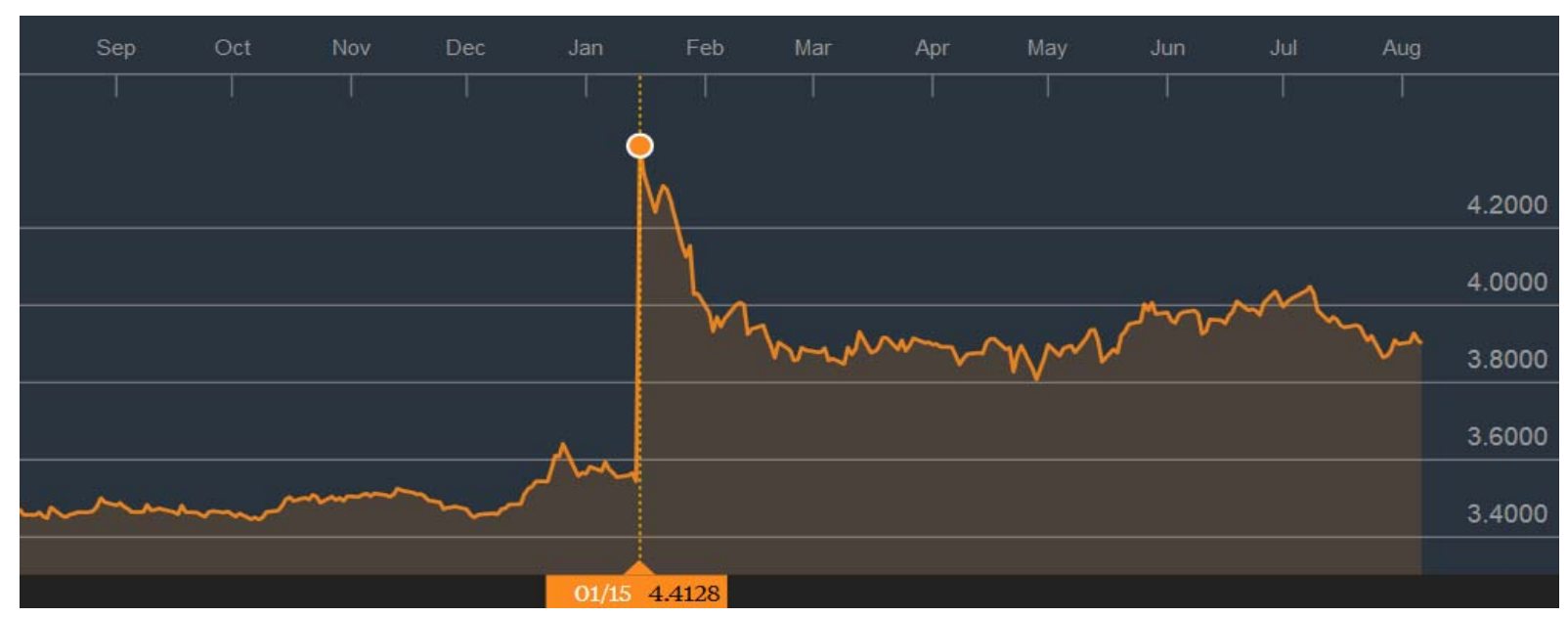

Fig. 1. CHF/PLN exchange rate from 6 August 2014 to 6 August 2015. Source: http:/ / www.bloomberg.com/quote/CHFPLN:CUR, 6.08.2015.

This decision has, and most certainly will continue to have for a long time, many consequences for various market participants, including the banking sector and those who took out loans in a foreign currency. The credit risk stemming from exposing borrowers to changes in the exchange rate of currencies and foreign interest rates is one of the main risk factors connected with foreign currency loans (NBP 2015b).

\section{Determinants and consequences of currency risk}

Observing the phenomena taking place on the relatively young Polish market of mortgages makes it possible to state that it is subjected to dynamic changes, often influenced by changes in legal- 
regulatory laws shaping the priorities of the credit policy of banks and the resulting, among others, availability of loans, as well as the country's instruments of intervention, by introducing, e.g. support programs, especially in the scope of financing residential housing.

Among the many risks connected with financing the real estate market are, i.e. currency risk, resulting from the granting of bank loans in a foreign currency (so-called foreign currency loans) or denominated by the exchange rate of a foreign currency (GŁóWKA 2012, pp. 82-84, 197; SIEMIŃSKA 2013, pp. 178-179).

Currency risk, otherwise referred to exchange-rate risk, results from "changes in the currency exchange rate on the market and affects those (...) assets or obligations whose value depends on the exchange rate" (Zarzadzanie ryzykiem, 2007, pp. 18). It is worth emphasizing here that changes in the exchange rate can have, and in practice do in fact have, a positive as well as negative consequence for the given entity possessing the mentioned assets or obligations. In the case of mortgages denominated in a foreign currency, the second situation takes place when, under the influence of the increase in the exchange rate, the value of the credit obligations increases because the value of the Polish currency decreases in relation to the currency in which the given loan is denominated.

The level of demand for loans in a foreign currency and the scale of their popularization are, to a large degree, shaped under the influence of differences in the level of interest rates (GŁóWKA 2012, p. 82). In Poland, similarly to many other countries, mortgages denominated especially in Swiss francs were, until recently, a very popular loan product, keenly granted by the banking sector. It was not until the dynamic changes and turbulences on the world markets caused by the first financial crisis of the XXI century on such a large scale that caused the successive introduction of restrictions and regulations aimed at increasing the safety and transparency of the financial sector by following countries and unions (PETRU 2014). Some of them also refer to restricting the exchange rate risk based on the principle that a foreign currency loan should be granted only to those people who receive income in the currency of the given loan.

Thanks to regulations introduced by the Financial Supervision Authority, regulating and sometimes even restricting the level of mortgage availability in Poland, especially the several-times modified Recommendation $S$ on good practice regarding managing mortgage-backed credit exposures (Recommendation S, 2013), the share of foreign currency loans, including mainly those in Swiss francs, in the bank credit portfolio for the non-financial sector is systematically declining (Fig. 2). Their current state is the legacy of the credit boom in Poland of 2006-2008, which never again regained its former levels, especially that banks practically ceased to grant loans in Swiss francs in 2012 (SYPUŁOWSKI 2015; SIEMIŃSKA, RYMARZAK 2014). The decrease in the volume of mortgages granted in the currency of Switzerland stems also from the fact that they are "aging" and being successively paid off by households.

According to data from the Loan Information Office (Biuro Informacji Kredytowej - BIK), at the end of November 2014, of 953 thousand people who had loans in Swiss francs, there were 566 thousand active mortgages, the value of which amounted to 137.1 billion PLN. Moreover, the analysis of BIK showed that as many as $96 \%$ of the loan recipients holding a home mortgage in francs (i.e. 914.66 thousand people) make timely payments on their loans (BIK 2015). It is worth emphasizing here that, according to numerous reports and analyses of the Polish Banking Union, Polish Financial Supervision Authority or National Bank of Poland, it turns out that, on the whole, the quality of the foreign currency portfolio in the Polish banking sector is better than the quality of analogical loans taken out in zlotys (SIEMIŃSKA 2013, pp. 183-186).

According to experts from the financial sector, the current increase in the level of mortgage installments denominated in Swiss francs for households, resulting from the increase in the level of the CHF/PLN exchange rate as compared to the level when most of foreign currency loans were granted, is not expected to significantly decrease the collectability of these loans (KOTOWICZ 2015, p. 9)

Interesting conclusions come from the comparative analysis of simulating the financial burdens of borrowers who had taken out foreign currency mortgages, as well as the influence of changes in the currency exchange rate and interest rates on the value of these credit obligations. The simulation of installments was carried out on three examples, i.e. loans granted in July 2006, July 2007 and July 2008, under the assumptions that the value of the mortgage is 300,000 PLN, and the loan was granted for a period of 30 years, paid out in one tranche, with the interest rate on it resulting from the level of the LIBOR CHF 3M rate (for loans denominated in the Swiss franc) and respectively the WIBOR 3M rate (for loans in PLN), increased by the average markup in the sector for the moment the given loan was 
granted (Fig. 3). The years of granting loans selected for the analysis (2006-2008) are not random, as they pertain to the period when the growth dynamics of home mortgages granted in the segment of households was the highest (Fig. 4), and the exchange rate of the Polish zloty was strong. The analysis also covers the effects of the appreciation of the Swiss franc on 15 January 2015, following the decision of the National Bank of Switzerland to scrap the cap on the franc-euro rate (NBP 2015b, p. 35).

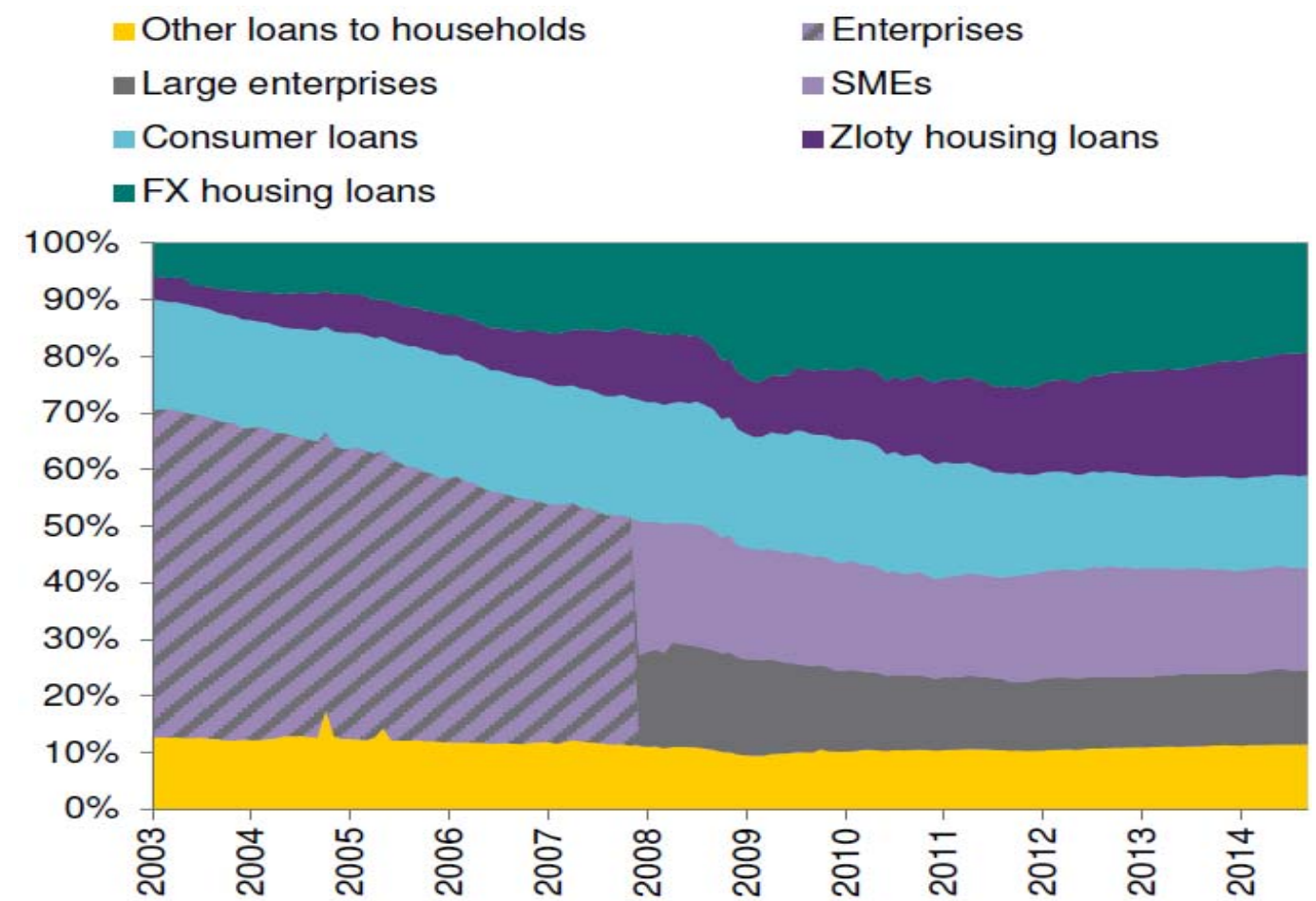

Note: the hatched area indicates the share of loans to the whole enterprise sector in the period when data broken down into loans to large enterprises and SMEs were not available.

Fig. 2. Structure of bank loans for the non-financial sector in the years 2003-2014 (in \%). Source: Financial Stability Report, NBP 2015, p. 28.
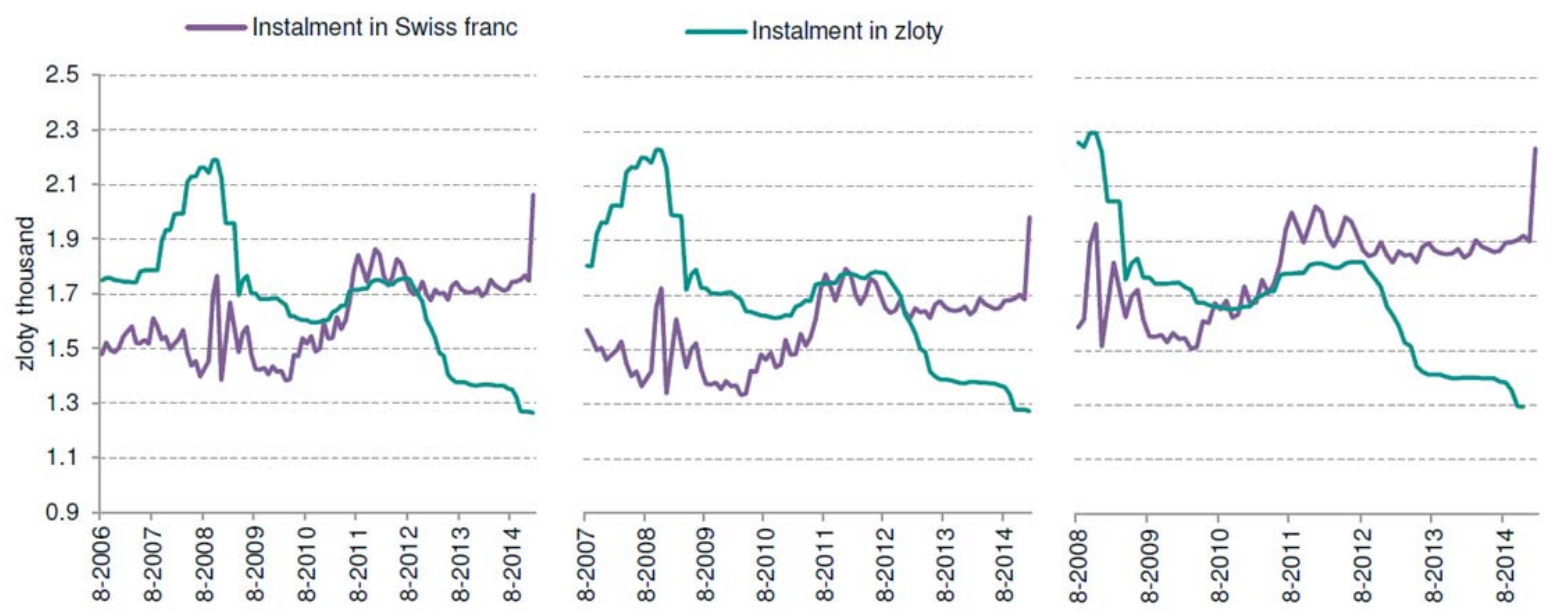

Please note: The currency spread, fees and provisions, as well as the costs of insurance were not accounted for in the calculations.

Fig. 3. Value (in zloty) of instalments for housing loans denominated in the Swiss franc and zloty granted in July of 2006 (left-hand panel), 2007 (middle panel) and 2008 (right-hand panel). Source: Financial Stability Report, NBP 2015, p. 35.

The presented analyses show that, firstly, the value of the installments in Swiss francs, regardless of the time at which the loan was taken out, are currently higher than when they were granted, 
conversely to analogical loans taken out in zlotys. Secondly, the more favorable - in terms of total of loan obligations - situation for loan recipients who took out loans in Swiss francs in 2006 and 2007 as compared to "zloty" loan recipients is observed. It is worth emphasizing this observation in the context of the widespread debate assumed by various bodies on the subject of the need for a possible reaction to the abrupt increase in the Swiss currency in relation to the Polish zloty.

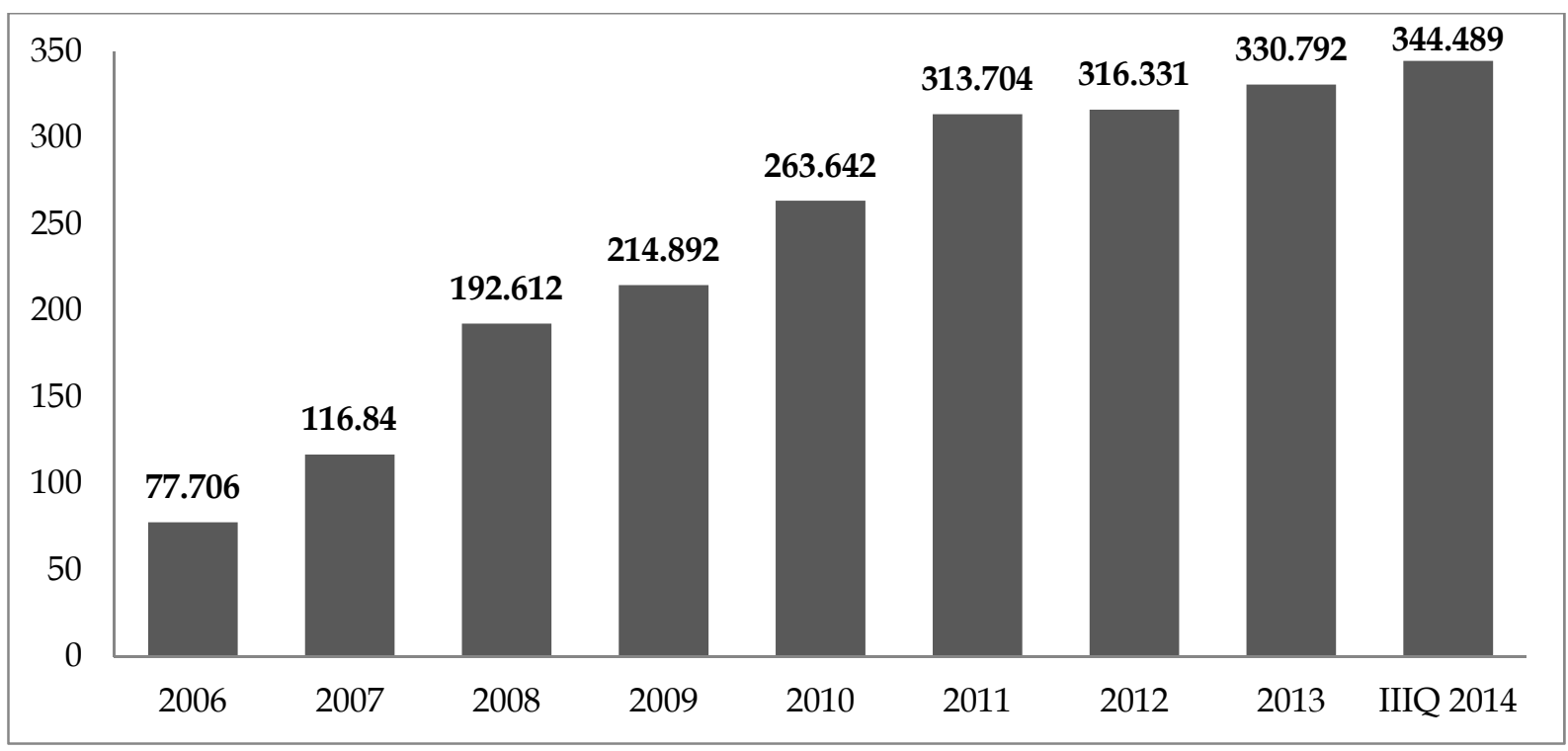

Fig. 4. Total amount of debt resulting from home mortgages taken out in the years 2006-3Q2014 (in billion PLN). Source: AMRON-SARFIN Report, 2014, p. 6.

When summarizing the presented simulation, one ought to add that the accurate assessment of the consequences of the Swiss currency becoming significantly stronger in relation to the Polish zloty would require accounting for specific knowledge on, first of all, the specific parameters of individual loan contracts entered into with the clients, and secondly, on the topic of the current financial situation of debtors, on which the ability to service debt is directly dependant. Unquestionably, the scale and further dynamics of changes in the currency of the Swiss franc will directly influence the level of the accumulated value of credit obligations and the costs of paying them off in the future.

An additional problem, identifiable not only on the Polish financial market, is the phenomenon of the so-called "trapped in debt". This regards borrowers whose level of debt increases despite making regular payments on their loans due to the increase in the exchange rate of the currency in which they were taken out. At the same time, the inability to change the mortgaged dwelling to, e.g. a larger one or one located elsewhere, as banks in Poland de facto didn't used to agree to transfer (sign over) a mortgage securing their claims to a different real estate, is also not a consequence of the situation to be ignored. In the wake of problems connected with this situation declared more and more frequently by some of the borrowers, and criticism of earlier, not always responsible, practices and behaviors of some workers of the financial sector, the majority of banks introduced a more flexible approach to settlements with debtors. What is more, in practice, the described phenomena encourage some borrowers to change the currency of their loans over to, for example, the national currency, which in the end, however, may not always turn out to be cost-effective and oftentimes brings about additional expenses.

Another effect of exchange rate risk is the problem of the inadequacy of the collateral for the mortgage following an increase in the exchange rate of the currency in which it was granted. The loan to value (LTV) level, as a parameter measuring the relation of the value of the loan to the value of the collateral, thus the valued real estate, will change under the influence of the assessment of the value of the mortgage accounting for the current exchange rate of the currency it was taken out in (BORGERSEN T. A., GREIBROKK J. 2010; KUCHARSKA-STASIAK 2013; KUCHARSKA-STASIAK 2014). According to data from the Polish Financial Supervision Authority, at the end of 2013 the banks had 562.5 thousand loans in Swiss francs in their loan portfolios (which comprised $31.8 \%$ of their total number), with an average value of 241.2 thousand PLN. As assessed from this pool, the highest risk is posed by: 
1) 135.5 thousand loans in francs with an LTV of over $100 \%$, with a combined value of 54.5 billion PLN and

2) 67.8 thousand loans in Swiss francs with LTV at a level of $80-100 \%$, with a combined value of 22.7 billion PLN [KNF 2015, pp. 12-14].

Following the observed weakening of the Polish currency in relation to the Swiss franc, especially since the beginning of 2015, the structure of the loan portfolio of banks can be expected to worsen due to the increased share of loans with an LTV of over $100 \%$, which would require creating additional write-downs. Simulations carried out for testing extreme situations (stress tests) indicate that (Fig. 5):

1) "at an exchange rate of $\mathrm{CHF} / \mathrm{PLN}=4.2$, the value of mortgages in CHF would increase by approximately 25.7 billion PLN, the financial result would decrease by approximately 1.9 billion PLN, and the ratio of core equity capital CET 1 by approximately $0.7 \%$,

2) "At an exchange rate of $\mathrm{CHF} / \mathrm{PLN}=5.2$, the value of mortgages in CHF would increase by approximately 65.5 billion PLN, the financial result would decrease by approximately 6.3 billion PLN and the ratio of core equity capital CET 1 by approximately 1.7\%" (KNF 2015a, p. 11),

3) Each depreciation of the zloty leads to poorer financial results of the banking sector and lowers the core equity capital ratio required by banks (CET 1).

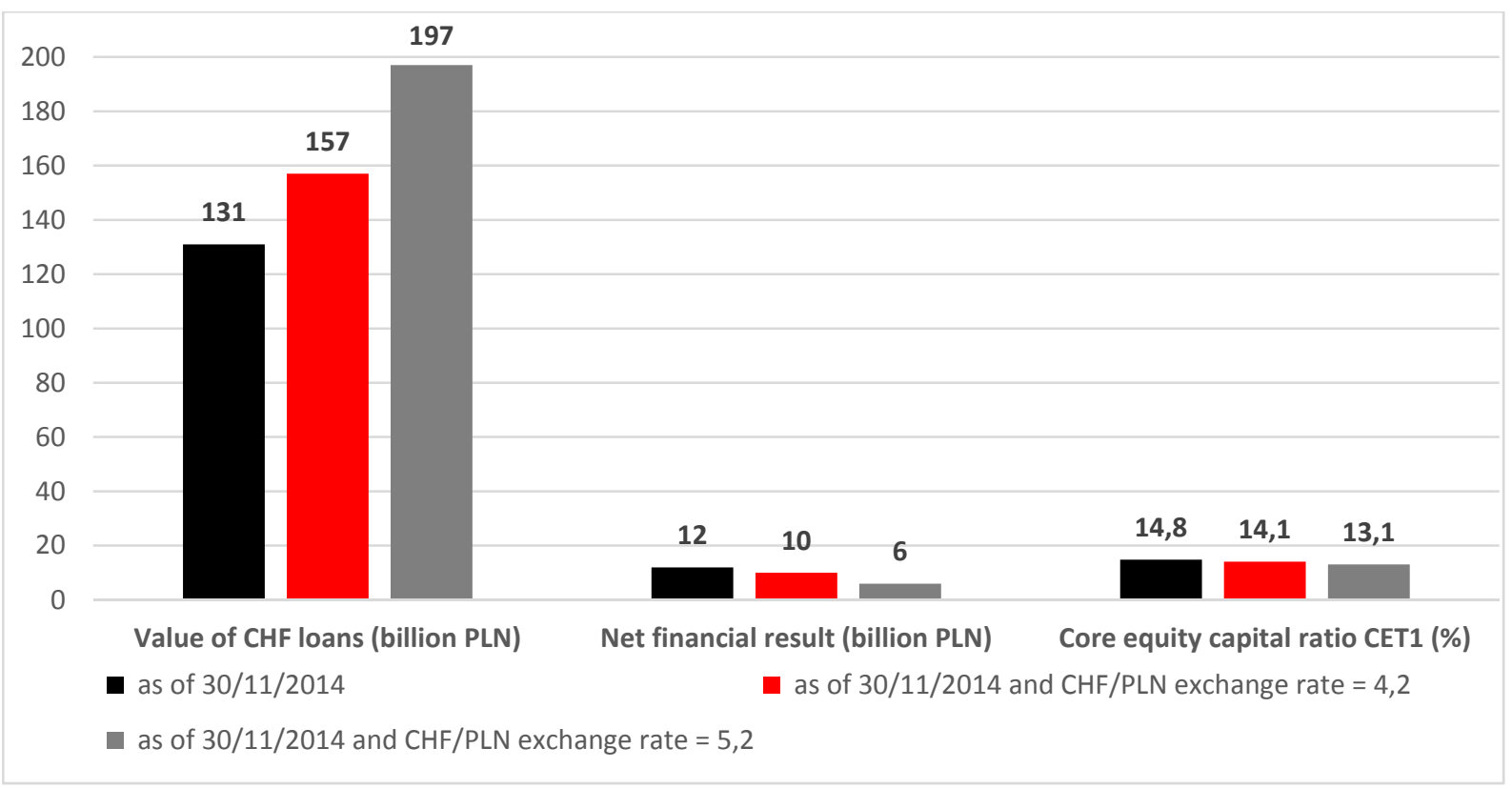

Fig. 5. Consequences of PLN weakening in relation to CHF (on the basis of stress tests). Source: KNF 2015a, 12.02.2015.

Results of stress tests published in October 2014, and a review of the quality of assets in Polish banks carried out by the Polish Financial Supervision Authority confirm the generally good situation of the banking sector and its high resistance to shock scenarios. Out of the 15 banks covered by the study $^{1}$, whose assets comprise close to $72 \%$ of the total bank assets and $79 \%$ of commercial bank assets, the risk of insufficient CET 1 finances was confirmed only in the case of two, which is not very significant considering the scale of the sector (insufficiency valued at 379.9 billion PLN, which is equivalent to $0.35 \%$ of the CET 1 funds of the sector). Similarly to the earlier successively carried out studies of the quality of the loan portfolio of Polish banks, the above-cited recent analyses also confirm a good level of the capitalization of the banking sector and mentioned high resistance to external shocks (KNF 2014). Nevertheless, banks which have a relatively high share of foreign currency loans in their loan portfolios, including those in Swiss francs, will surely feel the impact of exchange rate risk (Fig. 6).

${ }^{1}$ The study encompassed entities dependant on European Banks covered by stress tests (systematically important bank, stock exchange bank, bank quoting WIBOR/WIBID rates ). 


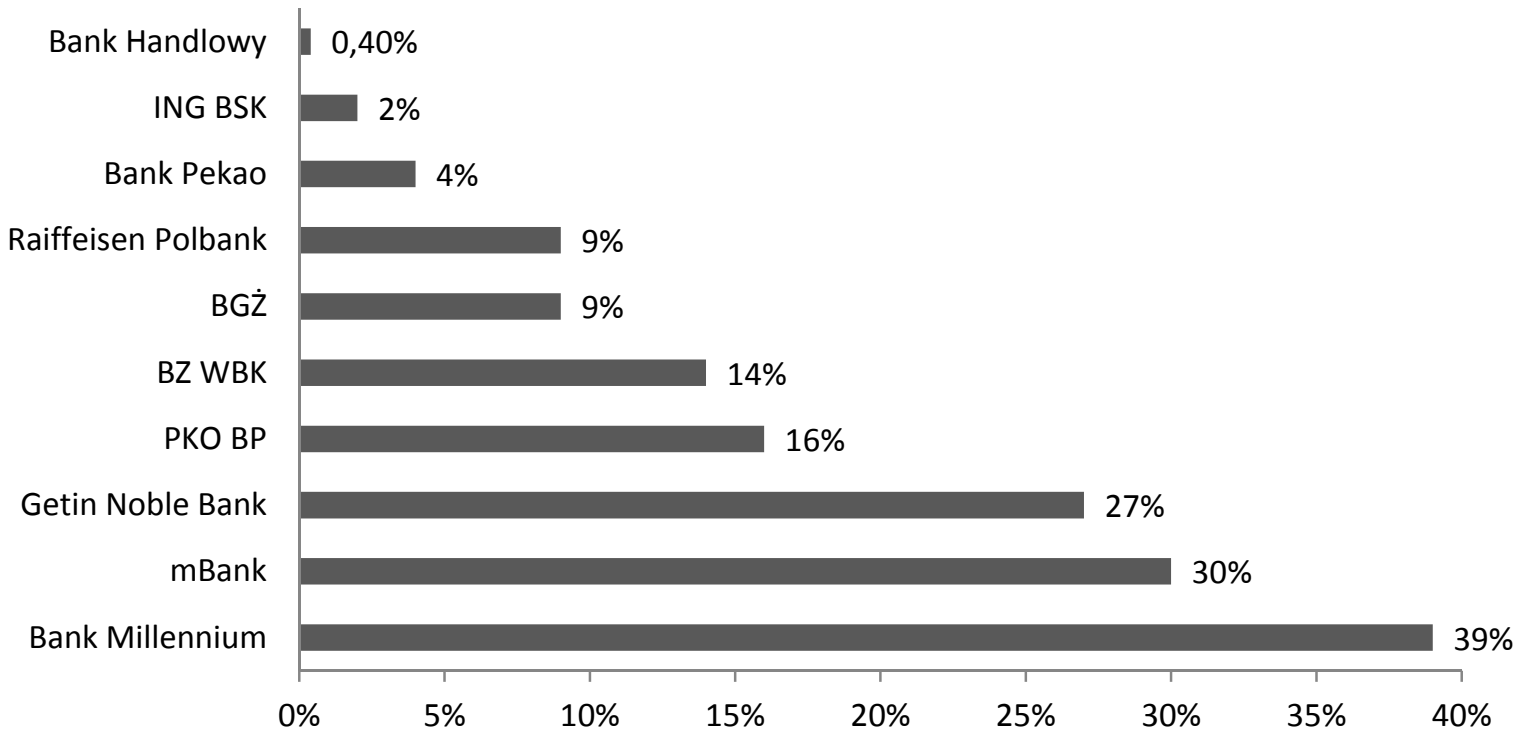

Fig. 6. Share of loans granted in Swiss francs in the loan portfolios of various banks (\%). Source: www.money.pl, 12.02.2015.

\section{Proposals of solutions for limiting the effects of exchange rate risk on the Polish market}

Upon announcing the decision of the National Bank of Switzerland to unpeg the franc in the middle of January 2015, various proposals for responding to the altered situation of many borrowers possessing loans in the Swiss franc began to arise with large intensity, not only in the Polish public sphere.

According to experts of the National Bank of Poland and Polish Banking Union, the negative effects of the mentioned appreciation of the Swiss franc ought to be largely mitigated by the observable decreasing tendencies of the market interest rate levels, falling even to negative values, accompanying this phenomenon (KоTOWICZ 2015, p. 9; KNF 2015a; NBP 2015a; NBP 2015b). Among actions aimed at alleviating the effects of the significant increase in the exchange rate of the Swiss franc in relation to the Polish currency (in January 2015) geared towards borrowers holding mortgages denominated in CHF and introduced up to the middle of February 2015 by some banks ${ }^{2}$, we can list:

1) a visible decrease of so-called currency spreads (e.g. from a level of $4-6 \%$ to a level of $0.5-1.5 \%$ ),

2) the possibility of extending the period of paying off the loan within the scope of the maximum repayment period,

3) banks holding off from requiring additional loan collateral connected with the increase in LTV so-called insurance of low own contribution,

4) the possibility for applying for forbearance periods of a couple of months.

At the beginning of 2015, only two of the ten analyzed banks announced accounting for the negative level of the LIBOR CHF rate in the cost of a mortgage; the remaining banks, looking into the situation, are analyzing the possibility of implementing system mechanisms in this regard. A portion of the banking community even expresses the opinion that it is not possible to account for negative levels of the LIBOR rate.

On the other hand, the Financial Supervision Authority in its stance taken on 2 February 2015 recommending that protective actions be introduced depending on the individual situations of borrowers - announced, among others, the possibility of converting loans taken out in Swiss francs to the Polish currency, even at an exchange rate equal to that on the day the loan was taken out, though under the condition that the borrower will cover the difference between the actual cost of repaying the loan and the cost resultant from paying off the loan in zloty (KNF 2015b). It is worth noting that this postulate was rather cautiously received by the banking community, which called for the necessity of

\footnotetext{
2 The analysis covered the following banks in Poland: BGŻ, BZ WBK, BNP PARIBAS, CREDIT AGRICOLE, DEUTSCHE BANK, GETIN NOBLE BANK, ING BANK ŚLĄSKI, mBANK, MILLENNIUM, PKO BP.
} 
precisely establishing the financial consequences of such a proposition prior to its possible implementation.

The legal community also joined the search for system changes, with lawyers indicating, among others, that on the grounds of civil law, there is no possibility of applying the rebus sic stantibus clause, which allows for changing the initial commitment resulting from the conditions of the contract in court under the condition of extraordinary alteration of social relationships; it is difficult to treat even significant changes in currency exchange rates as such. As a consequence of this, lawyers most often indicate the possibility of pursuing the claims of borrowers resultant from losses connected with exchange rate risk on the basis of abusive clauses that may be contained in loan contracts. In such cases, individual or group claims can be pursued by means of civil actions. An example is, among others, the verdict of the Court of Competition and Consumer Protection of 14 December 2010 No. XVII AmC 426/09, agreed on by the Court of Appeals in Warsaw in its verdict of 21 October 2011 (ref. No. VI ACa 420/11), which deemed loan contracts with so-called indexing clauses recalculating loans granted in zlotys to the exchange rate of the Swiss francs invalid. These are not unique examples of winning cases regarding unfair practices used by banks entering into mortgage contracts with clients in court (SZYMAŃSKI, MIKOŁAJEK 2015).

\section{International examples of regulations pertaining to exchange rate risk of mortgages}

It turns out that problems with foreign currency loans and the exchange rate risk associated with them are also present in other countries. Advantages coming from favorable exchange rates at a given time make for a large group of interested entities. What is more, the irresponsible granting and taking out of loans, and moral hazard of many market participants, including loan agents, took place on many mortgage markets. This is why many countries nowadays have problems, among others, with exchange rate risk on the financial market. This is confirmed, among others, by the European Parliament Directive of 2014 indicating that "... a series of problems have been identified in mortgage markets within the Union relating to irresponsible lending and borrowing and the potential scope for irresponsible behavior by market participants including credit intermediaries and non-credit institutions. Some problems concerned credits denominated in a foreign currency which consumers had taken out in that currency in order to take advantage of the borrowing rate offered but without having adequate information about or understanding of the exchange rate risk involved. Those problems are driven by market and regulatory failures as well as other factors such as the general economic climate and low level of financial literacy." (DIRECTIVE 2014).

The European Court of Justice and European Fair Trade Association (EFTA) stated, among others, that in index contracts based on the exchange rate of a foreign currency, the exchange rate of this currency is used only to determine the amount of the loan payment, thus charging for so-called currency spread by banks in unfounded, as the bank is not providing currency exchange services.

In Iceland, when the Supreme Court deemed indexed contracts invalid in 2010, it became necessary to covert the currency of loans at the exchange rate from the day they had been granted. This was because the court declared that it was not possible to apply an index to covert the principle of the loan and interest on it to a foreign currency.

In Hungary, which was first to decide to radically end the problem of foreign currency loans by helping its citizens pay them off in 2011, the problem became more complicated upon announcing the verdict of the Hungarian Supreme Court (referred to as the Kuria) at the end of 2014. The court declared that foreign currency loans in this country are legal and, what is more, indicated that having better conditions to pay off foreign currency loans than those granted in forints, clients should be aware of the exchange rate risk that accompanies such credit commitments. Following this verdict, the government of Prime Minister Victor Orbana assumed actions which made it possible to covert loans in francs by applying the average market exchange rate (256 forints for 1 franc and 309 forints for 1 euro). It is estimated that the program of saving borrowers in foreign currency debt cost the banks close to 1.5 trillion forints, the equivalent of approx. 5\% of Hungarian GDP, with the greatest losses (approx. 1 trillion forints) resulting from converting 495 thousand foreign currency loans into forints on the 1st of February 2015 (ZSEBESI 2015).

In Spain, in the middle of 2014, a law was passed on the measures for increasing the protection of mortgage debtors, debt restructuring and social housing, which is aimed mainly at protecting citizens from 
social exclusion caused by their problems meeting mortgage obligations. Increasing the scope of debtor protection can be based on, among others:

1) suspending, for two years, the expropriation of families, particularly at risk of social exclusion,

2) a fixed interest rate, set out by the law (at a level of $2 \%$ ) on loans which could not be paid off, and interest charged on the overdue loans,

3) the possibility of suspending the out-of-court sale of real estate serving as collateral for bank claims in situations defined by the law.

On the other hand, the financial regulator in France - Autorité de contrôle prudentiel (ACP - a counterpart of the Polish Financial Supervision Authority) issued, in 2012, the principles of good practice regarding the selling of foreign currency loans, that is loans connected with exchange rate risk, to private individuals. These recommendations apply to banks and their agents, and were prepared following two court proceedings of 2012 regarding unfair practices used by BNP Paribas and Crédit Agricole.

Examples of court verdicts regarding unfair practices applied by banks when selling foreign currency mortgages in other countries (France, Germany, Austria, Great Britain, Hungary, Croatia and Spain) indicate the increasing awareness of loan borrowers on the subject of market risk, including exchange rate risk, and their rights in relations with banks.

\section{Summary}

The far-reaching and often heated discussion of various market participants on the topic of exchange rate risk that comes up in many forms of media, intensified especially during periods of big fluctuations in currency exchange rates, indicates the significance of such risk, both at the lowest level of a household as well as at the level of national budgets and supranational entities. This risk also appears in the fact that the change in the level of the exchange rate of a given currency at a specific time not only influences the level of the exchange rate of one country's currency, but simultaneously, to varying degrees, affects the exchange rate levels of other currencies, creating multiplier effects.

Surely making a decision regarding the choice of a given strategy of action requires the honest and multi-directional identification of the problem along with its consequences in a longer perspective. That is why decisions regarding the means and mechanisms which are potentially worth applying on the Polish market in response to the increase in the exchange rate of the Swiss franc at the beginning of 2015 require accounting for many aspects, including the combined benefits experienced up to date by borrowers who had taken out foreign currency loans in comparison to the burdens of "zloty borrowers", or interest rate risk, which is strictly connected with exchange rate risk. It is also difficult to avoid being under the impression that political media issues, which have nothing in common with economic calculations, which also accounts for the earlier indicated long-term and specific nature of mortgages, are present in the discussion on the topic currently taking place in Poland.

Moreover, the sample scenarios of how different countries deal with the problem of currency risk in financing the real estate market prove that there is no single, universal method of action, and that it is not until later that we can assess the effectiveness of such actions. The presented problem also has many other determinants and consequences which were not described here due to the limited framework of the present article. This refers to, among others, the merely mentioned interest rate risk which is especially important in long-term mortgage contracts, as well as the social and legal consequences of the potential realization (by banks and/or debt collection agencies) of measures for securing mortgage claims, including the quality and effectiveness of the debt collection process and debt enforcement proceedings, the possibility of initiating legal disputes regarding exchange rate risk on a larger scale, etc.

It can therefore be stated that the stability and transparency of the financial system ought to always be the guiding principle in its operation. This is seeing as how the weaknesses of the system have painful consequences, especially in situations of crisis, leading to the loss of what is most valuable and most difficult to gain and maintain - clients' trust.

\section{References}

BIURO INFORMACJI KREDYTOWEJ - BIK, 2015, Kredyt trendy (Credit Trends), www.bik.pl, 12.02.2015. BLOOMBERG, 2015, http://www.bloomberg.com/quote/CHFPLN:CUR.

BOLAET M., COLES A., 2012, The mortgage market, Routledge, New York, NY. 
BORGERSEN T. A., GREIBROKK J., 2012, Reflections on LTV, risk and incentives in mortgage markets, Journal of European Real Estate Research, Vol. 5 no. 3, pp. 199 - 210.

CASE K.E., SHILLER R., 2004, Is there a bubble in the housing market?, Cowles Foundation Paper No. 1089, Cowles Foundation For Research In Economics, Yale University.

DIRECTIVE 2014/17/EU of the European Parliament and of the Council of 4 February 2014 on credit agreements for consumers relating to residential immovable property and amending Directives 2008/48/EC and 2013/36/EU and Regulation (EU) No 1093/2010, Official Journal of the European Union, Volume 57, 28 February 2014, doi:10.3000/19770677.L_2014.060.eng.

GŁóWKA G., 2012, System finansowania nieruchomości mieszkaniowych w Polsce. Doświadczenia i kierunki zmian (System of Financing Residential Real Estate in Poland. Experiences and Directions of Changes), Oficyna Wydawnicza Szkoła Główna Handlowa, Warszawa.

GROSSE R., 2012, Bank regulation, governance and the crisis: a behavioral finance view, Journal of Financial Regulation and Compliance, Vol. 20 No. 1, pp. 4 - 25.

Jordan T., 2015, Introductory remarks by Thomas Jordan, The Swiss National Bank, www.snb.ch/en/mmr/speeches/id/ref_20150115_tjn/source/ref_20150115_tjn.en.pdf, 11.02.2015.

KALLAKMAA-KAPSTA A., KOLBRE E., 2013, Estonian housing market: affordability problem and regulatory framework, International Journal of Housing Markets and Analysis, Vol. 6 No. 2, pp. 146 - 162.

KAU J. B., KeEnAN D.C., LyUbimov C., SlaWSON C., 2011, Subprime mortgage default, Journal of Urban Economics Volume 70, No. 2-3, pp. 75-87.

KOMISJA NADZORU FINANSOWEGO - KNF, 2013, Rekomendacja S dotyczaca dobrych praktyk w zakresie zarzadzania ekspozycjami kredytowymi zabezpieczonymi hipotecznie (Recommendation S Regarding Good Practice in Terms of Managing Credit Expositions Secured by Mortgage), www.knf.gov.pl/Images/Rekomendacja_S_18_06_2013._tcm75-34880.pdf, 12.02.2015.

KOMISJA NADZORU FINANSOWEGO - KNF, 2014, Przegląd jakości aktywów i testy warunków skrajnych. Banki z Polski w analizie europejskiej (Asset Quality Review - AQR and Stress Tests), www.knf.gov.pl, 14.02.2015.

KOMISJA NADZORU FINANSOWEGO - KNF, 2015a, Wptyw silnego ostabienia PLN względem CHF na stabilność polskiego sektora bankowego oraz sytuację finansowa kredytobiorców, www.knf.gov.pl, 12.02.2015.

KOMISJA NADZORU FINANSOWEGO - KNF, 2015b, Propozycja Przewodniczacego KNF dotyczaca restrukturyzacji kredytów udzielonych w CHF, przedstawiona na posiedzeniu Komisji Finansów Publicznych w dniu 3 lutego 2015 roku (Influence of the Severe Weakening of PLN to CHF on the Stability of the Polish Banking Sector and Financial Situation of Debtors), www.knf.gov.pl, 12.02.2015.

KOTOWICZ A., 2015, Wpływ silnego osłabienia PLN względem CHF na stabilność polskiego sektora bankowego oraz sytuacje finansowa kredytobiorców (Influence of the severe weaking of PLN to CHF on the Stability of the Polish Banking Sector and Financial Situation of Debtors), Urząd Komisji Nadzoru Finansowego, Warszawa.

KUCHARSKA-STASIAK E., 2013, Uncertainty of property valuation as a subject of academic research, Real Estate Management and Valuation, Volume 22, No. 4, pp. 17-24.

KUCHARSKA-STASIAK E., 2014, Reproduction of Real Estate Valuation Methodology in Practice. An Attempt at Identifying Sources of Divergences, Real Estate Management and Valuation, Vol. 22/2, pp. 67-79.

NBP, 2015a, Kursy średnie CHF (Average Exchange Rates of CHF), www.nbp.pl, 12.02.2015.

NBP, 2015b, Financial Stability Report, January 2015, http://www.nbp.pl/en/systemfinansowy/ fsr201501.pdf, 10.02.2015.

Oatley T., Winecoff W.K., Pennock A., DanZMAn S.B., 2013, The political economy of global finance: A network model, Perspectives on Politics, Volume 11, No. 01, pp. 133-153.

Petru R., 2014, Koniec wolnego rynku? Geneza kryzysu (The End of the Free Market Economy? Genesis of a Crisis), Narodowe Centrum Kultury, Warszawa.

RAPORT AMRON-SARFiN, 2014, Ogólnopolski raport o kredytach mieszkaniowych i cenach transakcyjnych nieruchomości (Polish National Report on Housing Mortgages and Transaction Prices of Real Estate), Nr 3, Związek Banków Polskich, www.zbp.pl, 10.02.2015.

SIEMIŃSKA E., 2013, Ryzyka inwestowania i finansowania na rynku nieruchomości w kontekście etyki $i$ społecznej odpowiedzialności (Risks of Investing and Financing on the Real Estate Market in the Context of Ethics and Social Responsibility), Wydawnictwo Uniwersytet Mikołaja Kopernika, Torun.

SIEMIŃSKA E., RYMARZAK M., 2014, Development conditions of polish housing market during economic crisis, Real Estate Management and Valuation, Volume 22, No. 4, pp. 68-79. 
SYPUŁKOWSKI C., 2015, O naturze kredytu we frankach (On the Nature of Swiss Franc Loans), Rzeczpospolita z dnia 30.01.2015 r.

SZYMAŃSKI M., MiKOŁAJEK K., 2015, W obronie frankowiczów (In Defense of Franc Debtors), Rzeczpospolita $\mathrm{z}$ dnia 22.01.2015 r.

ŚMIETANA K., 2014, Diversification principles of real estate portfolios, Real Estate Management and Valuation, Volume 22, No. 1, pp. 54-60.

THE RICS, 2011, European Housing Review, www.fhbindex.hu/FHB-Index/Az-FHBIndex/RICS\%20Housing\%20Review\%202011.pdf, 12.02.2015.

Zarzadzanie Ryzykiem (Risk Management), 2007, red. JAJUGA K., PWN, Warszawa.

ZSEBESI Z., 2015, Wegrry lecza kaca po franku (Hungary Treating Franc Hangover), Forsal z dnia 11.02.2015. 